\title{
Puncak Ritual Kematian Suku Dayak Tonyooi Benuaq dalam Dokumenter Etnografi "Malas Budi Basaq"
}

\author{
Valenci Kalista \\ Alexandri Luthfi R \\ Agnes Widyasmoro
}

Jurusan Film \& Televisi, Fakultas Seni Media Rekam, Institut Seni Indonesia Yogyakarta

Jl. Parangtritis km. 6.5 Yogyakarta Telp. (0274) 381047

\begin{abstract}
ABSTRAK
Penciptaan karya dokumenter ini adalah puncak ritual kematian dalam suku Dayak Tonyooi Benuaq, yaitu kuangkai. Kuangkai dilaksanakan bertahun-tahun setelah seseorang meninggal, yakni saat tengkorak sudah bisa dipisahkan darai badan. Kuangkai merupakan bentuk balas budi yang dilakukan oleh pihak keluarga. Masyarakat adat yakin, apabila seseorang meninggal, roh mereka harus dijemput oleh leluhur agar dapat sampai ke surga. Sebelum ritual kuangkai, ada tahap parapm api dan kenyau yang dilakukan bertahun-tahun sebelumnya, ketika seseorang baru meninggal.

Dokumenter "Malas Budi Basaq" menggunakan metode etnografi agar penonton mengetahui pentingnya kuangkai berdasarkan sudut pandang masyarakat Tonyooi Benuaq. Pendekatan melalui metode ini membuat makna-makna yang terkandung dalam ritual kuangkai dapat disajikan dengan maksimal. Gaya ekspositori digunakan agar segala informasi mengenai kuangkai yang masih asing bagi sebagian besar penonton dapat tersampaikan dengan baik. Struktur kronologis dipilih untuk memaparkan tahapan ritual kuangkai yang berlangsung selama kurang lebih 14 hari.

Hasil karya seni ini menunjukkan bagaimana kedudukan kuangkai sebagai puncak ritual kematian bagi masyarakat Dayak Tonyooi Benuaq. Kuangkai tetap menjadi sebuah ritual yang sakral dan akan terus mereka laksanakan sebagai bukti penghormatan dan balas budi kepada rohroh leluhur.
\end{abstract}

kata kunci: kuangkai, etnografi, dayak tonyooi benuaq, dokumenter

\section{Pendahuluan}

Dokumenter etnografi "Malas Budi Basaq" adalah karya Tugas Akhir Skripsi Penciptaan Seni yang dibuat untuk memenuhi syarat kelulusan strata satu Jurusan Televisi, Fakultas Seni Media Rekam, Institut Seni Indonesia Yogyakarta. Ritual kuangkai pada suku Dayak Benuaq dan Tonyooi yang menjadi obyek dalam film ini. Dayak Tonyooi dan Dayak Benuaq merupakan salah satu subsuku Dayak Luwangan, yang merupakan subsuku Stammenras Ot Danum, dan termasuk dalam kelompok Barito di Kalimantan Tengah (Widjono, 2016: 98). Kedua suku ini mendominasi wilayah Kabupaten Kutai Barat, Kalimantan Timur.

Suku Dayak Benuaq dan Dayak Tonyooi memiliki adat istiadat dan kearifan lokal yang unik. Keunikan itu salah satunya nampak dalam ritual adat kematian yang memperlihatkan bagaimana korelasi hubungan mereka dengan para roh keluarga yang telah meninggal. Mereka memiliki keyakinan kalau roh orang yang meninggal 
harus dijemput oleh para leluhur agar sampai ke surga. Keistimewaan lainnya terdapat pada sikap sebagian besar masyarakat Tonyooi Benuaq, yaitu meskipun mereka telah memeluk agama, namun tetap melaksanakan ritual adat.

Terdapat tiga tahapan ritual kematian, yaitu parepm api, pekintuh/kenyau, dan kuangkai. Dari ketiga tahapan ritual kematian tersebut, dipilihlah kuangkai sebagai obyek program dokumenter. Hal ini karena kuangkai merupakan puncak tertinggi dari semua tahapan ritual kematian. Kuangkai merupakan bentuk ungkapan balas budi yang dilakukan oleh keluarga yang masih hidup kepada orang tua atau sanak saudara mereka yang sudah meninggal. Tujuan dari kuangkai adalah untuk mengantar roh ke tempat peristirahatan terakhir yang layak, yaitu surga. Oleh karena itu dipilihlah "Malas Budi Basaq" sebagai judul film, yang berarti yang berarti balas budi jasa.

Ide penciptaan diperoleh melalui pengalaman selama 22 tahun menjadi bagian dalam masyarakat Dayak Tonyooi Benuaq. Kendati demikian, tumbuh dan berkembang di lingkungan perkotaan mengakibatkan kurangnya pemahaman mengenai adat istiadat sendiri. Ketertarikan dengan kearifan lokal yang dimiliki Benuaq Tonyooi muncul seiring bertambahnya usia. Hal tersebut cukup unik dikarenakan sebagian besar sanak saudara yang merupakan generasi muda dari suku ini tidak memiliki ketertarikan dan rasa ingin tahu terhadap adat istiadatnya sendiri. Keprihatinan terhadap punahnya adat istiadat masyarakat Dayak, dalam hal ini Tonyooi Benuaq, karena tergerus oleh kemajuan zaman, akibat pengaruh agama, serta sedikitnya regenerasi pemimpin ritual adat merupakan awal munculnya ide untuk membuat karya dokumenter ini.

Metode etnografi dipilih karena metode ini mengedepankan pendekatan secara partisipasi dan observasi, sehingga data-data penting yang mendukung proses produksi film ini dapat dikumpulkan secara maksimal. Melalui metode ini, gambaran mengenai adat istiadat serta kebudayaan Tonyooi Benuaq dapat dideskripsikan dengan baik. Sifat holistik dan integratif dalam etnografi membuat film ini secara keseluruhan mampu menampilkan wajah masyarakat Tonyooi Benuaq yang apa adanya. Selama proses risetnya, film ini menggunakan penelitian lapangan, yaitu ciri khas dari antropologi budaya.

Pemilihan gaya ekspositori dalam dokumenter ini agar semua informasi yang disampaikan dapat diterima dengan baik oleh penonton, terutama penonton yang berasal dari luar suku Tonyooi Benuaq. Penjelasan mengenai tahapan ritual beserta maknanya harus disampaikan secara tersurat agar tidak terjadi kesalahan dalam menafsir. Struktur kronologis digunakan untuk membentuk film ini, sehingga alur cerita yang merupakan 
tahapan ritual kuangkai dapat dipaparkan secara berurutan. Film dibagi menjadi tiga bagian, pembukaan yang merupakan pengenalan singkat mengenai Dayak Tonyooi Benuaq, isi film yang menjelaskan tahapan ritual kuangkai, serta penutup yang memperlihatkan dampak ritual tersebut terhadap masyarakat Tonyooi Benuaq.

\section{Pembahasan}

Kuangkai dilakukan oleh keluarga yang ingin mengantar roh anggota keluarga mereka yang sudah meninggal ke tempat peristirahatan terbaik di alam baka. Kuangkai dapat dilaksanakan setelah lima tahun sejak sanak keluarga tersebut meninggal. Pada proses kuangkai, pemimpin ritual kematian yang disebut pengewara memanggil roh para leluhur untuk mengantarkan roh yang baru agar dapat sampai ke surga. Sesaji dan hewan-hewan yang dikurbankan dalam upacara ini merupakan bekal roh selama perjalanan pulang dan menjadi harta mereka di surga.

Melalui metode etnografi, makna dari setiap rentetan upacara kuangkai dapat diperoleh secara maksimal. Pendekatan menggunakan metode etnografi sangat membantu untuk memposisikan diri sama seperti penduduk lokal sehingga dapat terjalin kedekatan yang lebih intim dengan mereka. Sudut pandang dari masyarakat Tonyooi Benuaq dapat diperlihatkan dan makna yang diperoleh tidak terdistorsi dengan interpretasi sepihak. Korelasi antara masyarakat Dayak Tonyooi Benuaq dengan roh-roh leluhur mereka sangat ingin ditonjolkan dalam film ini.

Pada dasarnya masyarakat Tonyooi Benuaq percaya jika seseorang meninggal, wujudnya akan menjelma menjadi tiga roh, yaitu roh liau, roh kelelungan dan roh aning tulakng. Liau merupakan roh badan atau roh daging. Bila seseorang meninggal, badannya pasti hancur, namun roh badan masih hidup. Liau adalah roh yang pemarah, karena merupakan perwujudan dari sifat manusiawi seseorang. Kelelungan adalah roh jiwa atau roh tengkorak yang tidak bisa hancur. Kelelungan sudah ada sejak manusia lahir dan akan terus hidup walaupun raganya mati. Sifat-sifat luhur manusia berasal dari kelelungan. Aning tulakng adalah roh tulang sendi yang terdapat pada sendi dan tulang-belulang seseorang. Roh aning tulakng bersemayam dikuburan orang tersebut.

Masyarakat Tonyooi Benuaq meyakini adat dapat berjalan seiringan dengan agama karena sejak dahulu mereka sudah mengimani Tuhan. Mereka memanggil Tuhan dengan sebutan "Latala". Adat istiadat menurut pandangan mereka merupakan tata cara berdoa kepada Tuhan yang dilakukan oleh para leluhur sejak zaman dahulu. Para leluhur berdoa dengan menyiapkan sesaji, persembahan, dan pengorbanan yang diwujudkan dengan 
menyembelih hewan kurban. Mereka beranggapan tidak ada salahnya berdoa dengan tata cara adat maupun dengan tata cara agama, karena inti dari keduanya adalah mengucap syukur kepada Tuhan.

Ada juga masyarakat Tonyooi Benuaq yang sudah meninggalkan adat istiadat. Mereka meyakini bahwa seluruh ritual adat bertentangan dengan ajaran agama karena tidak tertulis di dalam kitab suci agama tersebut. Ini tidak bisa disalahkan karena menyangkut keyakinan masing-masing pribadi. Hal yang disayangkan adalah banyak dari mereka tidak mau hadir dan terlibat dalam ritual adat yang diselenggrakan oleh keluarga mereka sendiri. Pudarnya semangat gotong-royong yang menjadi semboyan masyarakat Tonyooi Benuaq merupakan tanda kemunduran dalam sebuah hubungan bermasyarakat.

Catatan etnografi mengenai obyek diperoleh setelah melakukan riset mengenai obyek, yaitu ritual kuangkai selama kurang lebih tiga tahun. Berdasarkan catatan ini, dapat ditarik benang merah yang menjadi pedoman saat melakukan pengambilan gambar, sehingga mempermudah proses editing. Mempelajari narasumber, baik dari karakter dan sikap mereka saat berbicara dilakukan saat riset.

Pendekatan observasi - partisipasi yang menjadi ciri khas metode etnografi dilakukan agar bisa mengumpulkan data dengan maksimal. Observasi mengenai ritual kuangkai telah dilakukan sejak tahun 2014. Kunjungan ke Kutai Barat dan mendatangi rumah-rumah yang mengadakan ritual kematian dilakukan selama riset tersebut. Wawancara dilakukan dengan pemimpin ritual kuangkai pada setiap acara yang dikunjungi guna mengumpulkan data.

Sudut pandang dari penduduk asli Dayak Tonyooi Benuaq (native point of view) diperoleh dengan cara memperlihatkan subyek yang menjadi panutan dalam setiap rangkaian ritual kuangkai. Subyek tersebut merupakan pengewara yang menjadi narasumber utama dan telah terenkulturasi penuh. Beliau pemimpin ritual kuangkai di Desa Damai.

Pendekatan dengan narasumber utama dilakukan selama kurang lebih dua tahun melalui wawancara dengan prinsip konkuren. Wawancara dengan prinsip konkuren dipilih agar dapat menggali informasi mengenai ritual kuangkai serta segala hal lainnya yang berkaitan dengan ritual tersebut. Selain itu, hal ini dapat memudahkan saat proses syuting berlangsung karena pengewara tidak merasa risih atau canggung dengan adanya kamera yang digunakan untuk merekam seluruh rangkaian ritual kuangkai. Terjalinnya hubungan yang baik membuat ritual kuangkai dan proses pengambilan gambar dapat berjalan seiringan tanpa kendala.

Struktur penuturan kronologis sesuai dengan konsep penciptaan karya ini. 
Dokumenter etnografi "Malas Budi Basaq" hanya berfokus pada satu obyek dokumenter, yaitu ritual kuangkai dengan menampilkan bagaimana rentetan ritual tersebut secara berurutan. Alasan dipilihnya struktur kronologis agar penonton dapat dengan mudah memahami pengetahuan baru yang disajikan kepada mereka.

Dokumenter etnografi "Malas Budi Basaq" menggunakan wawancara dengan narasumber utama untuk menjelaskan tahapan ritual kuangkai dan narasi sebagai unsur penguatnya. Narasi tersebut berfungsi sebagai pengantar saat bagian pembukaan film, memperkuat pernyataan narasumber utama dalam menjelaskan rentetan ritual, serta menjadi penutup film. Narasi diperlukan untuk menjelaskan informasi abstrak yang tidak mampu digambarkan oleh shot-shot yang ada. Narasi juga dapat membantu menjelaskan kegiatan yang dilakukan oleh pengewara dan orang-orang yang turut serta dalam ritual kematian yang kemungkinan kurang dipahami oleh penonton.

Seorang etnografer harus mampu berhadapan dengan bahasanya sendiri dan bahasa informannya. Prinsip identifikasi bahasa digunakan agar tidak terjebak saat mendefinisikan berbagai istilah Benuaq. Selama proses pengumpulan data, pernyataan dari para narasumber dicatat secara harfiah dan tidak diringkas agar tidak ada istilah dan makna yang luput dari pengamatan etnografer.

Bahasa Benuaq dipilih sebagai bahasa pengantar dalam film ini, bukan bahasa Tonyooi karena seluruh doa dalam ritual menggunakan bahasa Benuaq. Selain itu, jika bahasa Indonesia yang dipilih menjadi bahasa pengantar film, banyak istilah Benuaq yang tidak dapat diterjemahkan dengan baik karena tidak memiliki arti dalam bahasa Indonesia. Cara agar penonton dapat memahami film ini adalah dengan penggunaan teks bawah pada film (subtitle) dalam bahasa Indonesia Alasan lainnya karena narasumber utama tidak dapat berbicara bahasa Indonesia dengan lancar. Apabila dipaksakan menggunakan bahasa Indonesia, khawatir membuat wawancara menjadi kaku. Besar harapan sutradara agar film ini mendapat sambutan baik dari khalayak luas dan masyarakat Benuaq Tonyooi itu sendiri.

Terdapat beberapa tahapan untuk menyutradarai dokumenter etnografi. Riset dalam kurun waktu yang lama dibutuhkan agar sutradara lebih mengenal obyek dokumenter, serta menciptakan kedekatan yang intim dengan subyek dokumenter. Ada baiknya jika memiliki lebih dari satu orang narasumber. Informasi-informasi dari mereka kemudian dirangkum dan dapat dijadikan suatu kesimpulan.Walaupun demikian tetap harus ditentukan narasumber utamanya. Berdasarkan hasil riset tersebut 
dibuatlah catatan etnografi yang kemudian menjadi pedoman saat melakukan proses pembuatan film dokumenter.

Proses pengambilan gambar sepenuhnya dilakukan di Kabupaten Kutai Barat, baik saat ritual maupun establish shotnya. Proses ini dilakukan oleh dua orang kru yang memang sudah memiliki kedekatan dengan masyarakat Dayak Tonyooi Benuaq. Gambar diambil dengan memperhitungkan posisi dari orang- orang yang berpartisipasi di dalam ritual ini. Melalui pendekatan etnografi yang baik, mereka yang melaksanakan kegiatan tersebut tidak merasa terganggu, bahkan sesekali mereka berinteraksi dengan kamera secara natural. Available light digunakan saat upacara di siang hari. Kemungkinan besar hanya menggunakan reflektor agar tidak tercipta shadow (bayangan) yang mengganggu di kamera. Saat malam hari akan digunakan lampu LED sebagai penerang, namun, penggunaan lampu ini juga menyesuaikan.

Secara keseluruhan, film ini mengunakan teknik editing cut to cut dan match cut. Editing juga menyesuaikan musik atau nyanyian yang mengiringi upacara adat. Musik yang dipakai untuk mengiringi film dokumenter etnografi “Malas Budi Basaq" merupakan musik yang dimainkan sepanjang ritual kuangkai berlangsung. Film ini tidak menggunakan scoring karena ingin menonjolkan musik ritual yang mistis namun sangat indah. Setting yang digunakan merupakan hasil respon terhadap lingkungan masyarakat Dayak Tonyooi Benuaq yang bermukim di Kabupaten Kutai Barat. Mulai dari rumah, peralatan adat, pakaian yang dipakai dan suasana perkampungannya.

\section{Sinopsis :}

Kuangkai merupakan puncak dari ritual kematian dalam Dayak Tonyooi Benuaq. Tujuan dari dilaksanakannya ritual kuangkai adalah untuk mengantarkan roh dari sanak saudara yang telah meninggal ke alam surga dengan bantuan para leluhur. Ritual ini sebenarnya tidak wajib untuk dilaksanakan karena memakan biaya yang besar, namun berdasarkan kesadaran pribadi dari setiap keluarga, kuangkai tetap dilakukan hingga saat ini. Mereka tidak ingin roh saudara atau orang tua yang mereka cintai tidak sampai ke surga dan mengganggu keluarga yang masih hidup.

Kuangkai yang dilaksanakan di Desa Damai, Kutai Barat telah memperlihatkan ritual kuangkai sesungguhnya, yaitu ritual yang masih mengikuti aturan adat. Dokumenter etnografi ini memperlihatkan bagaimana masyarakat adat menyadari pentingnya menjaga relasi dengan para leluhur. Acara berlangsung dari pagi hingga malam hari selama hampir satu bulan.

\section{Treatment :}

\section{a. Segmen 1}

Segmen 1 berisi pengenalan singkat terhadap suku Dayak Tonyooi Benuaq 
melalui narasi dan wawancara. Dilanjutkan dengan pengenalan ritual kuangkai. Shot-shot penting:

1) Establish awan yang menjadi gelap, simbol manusia yang kacau tanpa adat.

2) Shot-shot dikuburan.

3) Shot-shot ekspresi keluarga dan petugas acara.

4) Shot-shot yang menggambarkan suasana ketika membersihkan dan menyambut tulang-tulang.

\section{b. Segmen 2}

Pada segmen 2 dijelaskan bagaimana prosesi ritual kuangkai dan betapa pentingnya kuangkai dalam tahapan ritual kematian suku Dayak Tonyooi Benuaq. Dari banyaknya tahapan ritual kuangkai, yang ditampilkan adalah momen-momen krusial dari ritual kuangkai. Hal ini karena mempertimbangkan durasi. Lagi pula, hal yang paling penting ialah makna dari kegiatan tersebut dapat tersampaikan dengan baik. Tidak jauh berbeda dengan segmen 1, pada segmen 2 dipandu dengan wawancara narasumber utama serta narasi yang menggunakan bahasa Dayak Benuaq. Wawancara dan narasi bisa berupa penjelasan acara, penjelasan filosofi atau nyanyian dan pengucapan doa wara.

c. Segmen 3
Segmen 3 merupakan penutup dari film “Malas Budi Basaq". Pada segmen ini dijelaskan dampak yang terjadi setelah ritual kuangkai selesai dilaksanakan. Banyak sekali ekspresi kelegaan dan kebahagian karena pihak keluarga telah membalas jasa orang yang mereka sayangi dengan mengantarkan roh orang tersebut ke tempat peristirahatan yang tenang. Narasi yang akan mengiringi segmen 3 hingga selesai.

\section{Perwujudan Karya}

\section{Pra Produksi}

\section{a. Pencarian Ide}

Tahap pencarian ide merupakan tahapan paling dasar dalam membuat sebuah karya. Ketertarikan terhadap obyek muncul karena terlalu lama tinggal dan besar di lingkungan kota sehingga hampir tidak mengenal adat sendiri, meskipun dilahirkan sebagai Benuaq Tonyooi. Dorongan semakin besar akibat semakin banyaknya tokoh adat berkompeten yang sudah meninggal, tanpa sempat menurunkan semua ilmu yang dimiliki akibat tidak memiliki kemampuan membaca dan menulis. Hal ini diperparah dengan sangat sedikitnya generasi muda yang ingin mengenal adat mereka sendiri.

b. Riset

Beberapa hal menarik ditemukan selama melakukan riset dokumenter. 
Parepm api merupakan tingkatan yang wajib dilaksanakan, karena tanpa bantuan dari roh leluhur, roh yang baru meninggal tidak akan sampai ke surga. Tahap pekintuh atau kenyau dilaksanakan dengan harapan agar keadaan roh tersebut tidak susah saat di dunia mereka. Kuangkai memiliki tujuan yang sama dengan pekintuh dan kenyau, namun kuangkai merupakan penyempurnaan dari tahapan tersebut. Darah hewan kurban yang diusap pada tengkorak jasad yang dikuangkai merupakan tanda roh tersebut telah menjadi roh kelelungan yang sempurna, sehingga dapat mendoakan keluarga yang masih hidup.

Meskipun bukan sesuatu yang wajib dilaksanakan, kuangkai menjadi sebuah tanggung jawab moral bagi masyarakat Benuaq Tonyooi. Besar keinginan keluarga agar roh liau kelelungan orang yang mereka sayangi dapat merasakan kemakmuran seperti yang mereka rasakan saat ini, sehingga kuangkai diselenggarakan dengan maksud agar seluruh kurban dan makanan yang disajikan selama ritual dapat dibawa mereka ke surga.

Terjadi hubungan korelasi antara masyarakat Tonyooi Benuaq dengan roh- roh yang sudah meninggal. Apabila roh liau kelelungan bahagia, roh tersebut diyakini dapat mendoakan keluarga di dunia agar hidup bahagia dan murah rezeki. Roh liau kelelungan yang telah sempurna mampu menjadi perantara keluarga dengan Latala atau Tuhan Yang Maha Kuasa, sehingga mereka dapat dipersonifikasikan sebagai malaikat penolong.

Berdasarkan informasi yang diperoleh, saat ini ritual kuangkai sering dimanfaatkan oleh pihak tertentu untuk mencari keuntungan lewat judi dan sabung ayam, yang sebenarnya bukan merupakan bagian dari ritual kuangkai. Acara yang seharusnya hanya berlangsung maksimal selama 21 hariboleh lebih beberapa hari asalkan karena kendala tertentu-dapat menjadi dua sampai tiga bulan lamanya atau bahkan lebih.

c. Analisis Obyek

Analisis obyek dokumenter dilakukan dengan tujuan untuk memahami obyek dengan baik. Berdasarkan data yang diperoleh dapat ditentukan genre dan gaya dokumenter. Maka dipilihlah metode etnografi dan gaya ekspositori untuk diterapkan ke dalam karya ini. Pencatatan etnografi dilakukan pada tahap ini. Konsep visual juga dirancang guna mendukung pembuatan treatment.

\section{d. Menulis Treatment}

Setelah melalukan analisis obyek, banyak informasi mengenai kuangkai 
yang dapat dipahami dengan baik. Langkah selanjutnya adalah membuat treatment. Treatment yang menjadi panduan dalam produksi dokumenter etnografi ini dibagi menjadi tiga segmen, yaitu pembuka, isi, dan penutup.

\section{e. Rapat Produksi}

Setelah beberapa tahapan berhasil dilakukan, gagasan mengenai karya yang ingin dibuat dapat dibagi kepada tim yang membantu agar proses pengambilan gambar dapat berjalan lancar dan diperoleh hasil yang diinginkan. Melalui beberapa pertimbangan, akhirnya diputuskan untuk melakukan proses produksi di Kutai Barat dengan dua orang kru. Seorang menjadi director photography, seorang lagi sebagai sutradara merangkap kamerawan. Kru kecil dibentuk karena selain untuk menghemat anggaran, disisi lain agar lebih efektif dalam proses berproduksi.

\section{Produksi}

Ketika tahapan pra produksi telah selesai dilakukan, maka proses produksi dapat dilaksanakan. Berdasarkan waktu yang ditentukan, tim berangkat ke Desa Damai, Kabupaten Kutai Barat, Kalimantan Timur untuk melakukan proses pengambilan gambar. Di sana, sebuah keluarga menyelenggarakan kenyau kuangkai, di mana kenyau untuk jasad yang baru meninggal dan kuangkai untuk jasad di atas lima tahun yang sudah berwujud tulangbelulang. Saat kenyau berlangsung, dimanfaatkan sebagai masa penyesuaian serta pendekatan dengan para pengewara dan pihak keluarga, sehingga terjalin kedekatan yang intim. Harapannya yaitu tidak ada kecanggungan yang terjadi dan masyarakat Desa Damai tidak risih dengan adanya kamera yang merekam jalannya ritual. Saatsaat ini juga dimanfaatkan untuk mencari establish guna menambah shot-shot film.

Ritual kuangkai dilaksanakan di pada tanggal 19 Maret 2017 hingga 3 April 2017, dengan acara kenyau sebelumnya yaitu tanggal 12-18 Maret 2017. Walaupun ritual kuangkai hanya berlangsung 14 hari lebih 2 hari, namun tahapannya sama persis dengan ritual 21 hari. Ini karena periwayatan asalusul yang telah dimulai sejak acara kenyau, serta digabungnya tahapan-tahapan yang tidak terlalu memakan waktu pada hari yang sama. Seluruh kegiatan dilakukan selama 34 hari, terhitung dari keberangkatan dari Yogyakarta menuju Samarinda, perjalanan dari Samarinda menuju Kutai Barat, hingga kembali lagi pulang ke Samarinda.

Selama proses produksi, ditemukan beberapa fakta baru yang sebelumnya tidak diperoleh saat melakukan riset obyek dokumenter. Data-data baru itu menjadi penyempurna tahapan ritual ini. Berikut merupakan kelebihan ritual kuangkai yang diselenggarakan di Desa Damai, bila 
dibandingkan dengan kuangkai di tempat lainnya.

a. Pelaksanaan yang tepat waktu

Ritual kuangkai yang diadakan di Desa Damai termasuk tepat waktu, walaupun lebih tiga hari. Pihak keluarga memegang perkataan mereka dengan tidak melaksanakan kuangkai hingga berbulan-bulan. Mereka melaksanakan kuangkai sesuai dengan tradisi yang sudah ada.

b. Tidak ada konflik karena perbedaan keyakinan

Hal yang patut disyukuri karena kekhawatiran tersebut tidak terjadi. Saat kuangkai berlangsung, seluruh anggota keluarga saling bahu-membahu. Bahkan keluarga jauh yang berasal dari berbagai desa dan kecamatan ikut membatu dalam mempersiapkan segala macam kebutuhan kuangkai, walaupun tidak setiap hari.

c. Tahapan yang lebih lengkap

Terdapat beberapa tahapan kuangkai yang lebih lengkap bila dibandingkan dengan kuangkaikuangkai di tempat lainnya. Banyaknya temuan data baru tersebut tidak mengubah treatment yang telah dibuat sebelumnya. Ini karena sutradara berpegang pada struktur bertutur kronologis yang sangat membantu sutradara ketika menyusun tahapan ritual kuangkai. Berdasarkan semua data baru yang diperoleh, dipilihlah gambar-gambar yang sesuai dengan treatment yang telah dibuat.

\section{Pasca Produksi}

\section{a. Loading File}

Pada produksi dokumenter etnografi "Malas Budi Basaq" digunakan dua buah kamera DSLR dan tiga alat perekam suara. Semua peralatan yang digunakan menggunakan format digital, sehingga data-data dapat langsung dipindahkan ke komputer setelah syuting selesai dilakukan. Data-data tersebut dikelola dengan cara menyeleksi gambar-gambar yang ada, sehingga dapat dipilih gambar-gambar terbaik untuk mendukung cerita yang ingin dibangun. Tempat penyimpanan data menggunakan hardisk eksternal dengan kapasitas 2 terabyte agar tidak kepenuhan dan tidak lamban saat proses editing berlangsung.

\section{b. Editing Offline}

Pada tahap ini seorang editor bertugas untuk membangun struktur cerita. Tantangannya ialah editor tersebut harus mengerti bahasa Benuaq, sehingga rangkaian ritual kuangkai dapat disusun secara berurutan. Selain itu juga, kemampuan untuk memahami istilah-istilah dalam bahasa Benuaq dibutuhkan agar mampu menyesuaikan gambar dengan narasi yang juga menggunakan bahasa daerah, sehingga semua pesan yang ingin disampaikan 
dapat dirangkaikan dengan baik dan jelas. Pada tahap ini juga dilakukan perekaman narasi guna mendukung penjelasan film dokumenter.

\section{c. Editing Online}

Saat editing online dalam proses pembuatan dokumenter etnografi "Malas Budi Basaq", dilakukan beberapa hal sebagai penyelesaian pada tahap akhir editing. Hal-hal tersebut di antaranya memperbaiki warna yang tidak sama akibat penggunaan dua kamera yang berbeda, memperbaiki audio level serta menambahkan grafis sesuai kebutuhan. Tujuannya agar karya dokumenter ini dapat selesai dengan baik dan siap untuk ditonton.

\section{Pembahasan Karya}

\section{Unsur Sinematik}

\section{a. Elemen Gambar}

Konsep pengambilan gambar yang diusung dalam film ini adalah alami dan natural. Teknik pengambilan gambar menyesuaikan pergerakan obyek guna menangkap momen yang hanya terjadi satu kali. Penggunaan dua kamera DSLR untuk merekam tahapan ritual kuangkai agar tidak ada satupun momen yang terlewatkan. Aspek ratio menggunakan skala perbandingan 16:9 karena ingin menampilkan gambar yang sinematik namun tidak berlebihan.
Konsep pencahayaan yang digunakan adalah available light. Apabila dalam keadaan siang hari, matahari menjadi sumber penerangan utama. Saat malam tiba, maka digunakanlah lampu LED sebagai cahaya pengganti. Selain itu, segala hal yang berkaitan dengan setting merupakan respon dari tempat acara tersebut. Hal ini bertujuan agar film dokumenter etnografi "Malas Budi Basaq" dapat memperlihatkan sebuah keadaan sebenarnya, tanpa ada unsur rekayasa.

Setelah proses pengambilan gambar selesai dilakukan, seluruh data yang berbentuk digital diedit menggunakan Adobe Premiere CC 2015. Tahapan demi tahapan disusun berdasarkan urutan ritual agar tercipta sebuah karya dokumenter yang kontennya dapat dinikmati, dimengerti, dan pesannya dapat tersampaikan ke khalayak luas.

\section{b. Elemen Suara}

Pada elemen suara digunakan alat perekam suara genggam untuk menangkap atmosfer. Clip on juga digunakan saat pembacaan doa wara dan ketika melakukan wawancara, serta penggunaan mic portable yang dipasang di kamera. Film ini tidak memakai efek suara ataupun musik ilusrasi. Semua musik dan nyanyian doa pengewara dimanfaatkan untuk mengiringi film 
dokumenter etnografi "Malas Budi Basaq" ini.

\section{Unsur Naratif}

Tahapan Ritual Kuangkai

Pada dasarnya kuangkai memiliki rangkaian acara yang tidak terpisahkan. Setiap tahapan dalam kuangkai belum tentu dilaksanakan berturut-turut setiap hari. Kadangkala ada satu hari di mana tidak ada acara ritual, namun saat itu digunakan untuk persiapan ritual pada hari berikutnya yang membutuhkan banyak syarat. Berikut merupakan urutan scene dalam film dokumenter "Malas Budi Basaq". Tidak semua penjelasan dapat dimasukkan ke dalam film, akan tetapi garis besar dan makna dari setiap tahapan ditampilkan guna menjelaskan maksud dari kegiatan yang dilakukan.

\section{a. Segmen 1 (Pembukaan)}

\section{Pengenalan film}

Pembuka film ini menggunakan simeotika yang diawali dengan gambar langit cerah yang kemudian menjadi mendung. Ini melambangkan keadaan manusia yang menjadi kacau-balau apabila tidak mengenal adat istiadat. Kemudian dilanjutkan dengan judul film.

\section{Pesengket aning tulakng}

\section{(Pembersihan tulang di kuburan)}

Pesengket aning tulakng merupakan prosesi memasukan tengkoraktengkorak ke dalam rumah. Prosesi ini dimulai dari kuburan di mana jasad anggota keluarga disemayamkan. Setelah kuburan dibongkar, tengkorak dan tulang-tulang dibersihkan hingga tidak ada daging yang menempel. Tengorak- tengkorak tersebut diberi rokok, diolesi darah babi dan ayam, dan tidak lupa diolesi jomit burei oleh anggota keluarga. Kegiatan ini merupakan tanda penyambutan dari pihak keluarga, ucapan selamat datang kepada para roh.

Melakukan wawancara sebelumnya dengan penulakng membantu sutradara saat proses syuting, sehingga beliau tidak gugup saat ada kamera yang merekam. Sutradara telah dua kali mengikuti ritual pembersihan tengkorak saat melakukan riset mengenai kuangkai, sehingga saat proses pengambilan gambar tidak merasa kaget.

\section{b. Segmen 2 (Isi)}

\section{Ngerangkau (Menari bersama para roh)}

Menari ngerangkau merupakan tanda bahwa keluarga menyambut roh liau dan roh kelelungan yang telah datang dengan hati gembira. Tarian ini dibawakan dua kali, yang pertama oleh laki-laki dan selanjutnya perempuan.

Peturi kelelungan (Menidurkan roh-roh)

Setelah tarian ngerangkau laki-laki dan perempuan selesai, pengewara 
membacakan doa mempakng petehur ngerangkau sembari duduk mengitari kotak selimat. Maksud dari doa ini adalah mengajak roh liau dan roh kelelungan untuk duduk dan beristirahat sejenak setelah berpesta dan menarinari. Pada momen ini keluarga memperlihatkan perasaan mereka yang sebenarnya. Saat mengayun selimat atau kotak tempat tengkorak, terlihat ekspresi sedih pada raut wajah mereka. Prosesi yang mengharukan ini berlangsung setiap malam dan biasanya berakhir pada pukul satu malam.

Pesawaq belontakng (Pernikakan patung kurban dengan tali pengikat)

Pesawaq belontakng mengisahkan prosesi pernikahan antara belontakng dengan selampit. Belontakng memiliki ukuran yang besar sehingga sanggup untuk menahan kerbau atau sapi yang memberontak saat akan di tombak. Selampit adalah beberapa buah rotan yang dipilin menjadi satu dan memiliki panjang kira- kira sepuluh meter atau lebih. Selampit diikat pada moncong hewan kurban dan dihubungkan dengan belontakng. Tahap ini lebih lengkap karena ada peragaan pernikahan yang diwakilkan oleh dua anak laki-laki dan perempuan.

Pejiaq selew dan pejiaq jokatn boyas (Pembersihan perahu roh dan bahan makanan)
Pejiaq adalah kegiatan membacakan doa sambil mengibaskan seikat daun kering ke arah benda yang ingin dibersihkan. Selew merupakan ayunan yang digunakan untuk mengantarkan para roh saat malam terakhir. Sebelum digantung, selew harus dipejiaq terlebih dahulu agar bersih dari pengaruh buruk dan roh-roh jahat.

Boyas adalah sebutan untuk beras dalam bahasa Benuaq. Tujuan dari dilaksanakannya pejiaq jokatn boyas adalah untuk membersihkan bahan makanan, seperti beras putih, beras ketan, ayam, buah-buahan, sayur, minyak goreng dan bahan lainnya dari segala roh jahat serta pengaruh buruk. Sebagian dari bahan makanan tersebut dipersembahkan untuk para roh dan sebagian lainnya untuk keluarga. Pada akhir acara, apa yang menjadi jatah para roh akan diberikan kepada para pengewara sebagai upah mereka. Ini karena pengewara merupakan perwakilan dari semua roh.

Ngulaq belontakng (Menamam patung hewan kurban)

Kegiatan ngulaq belontakng atau tanam belontakng dilakukan di tengah lapangan yang luas. Belontakng yang ditanam berjumlah empat buah, sesuai dengan jumlah hewan kurban yang 
akan ditombak pada hari puncak. Lubang untuk menanam patung tersebut didoakan oleh pengewara agar bebas dari hal buruk dan roh jahat. Pengewara membacakan doa mempakng pada belontakng, sesaat sebelum patung ditanam dan setelahnya supaya roh leluhur berkenan memberkati patung belontakng tersebut.

\section{Tumakng wara (Penahbisan pengewara)}

Tumakng wara atau tumakng pengewara merupakan acara penahbisan seseorang menjadi pengewara. Ini juga adalah momen langka yangberhasil diabadikan. Pada kuangkai yang diselenggarakan di Desa Damai terdapat dua orang yang ingin ditahbiskan.

Pesalukng

(Menyambut kelelungan kedatangan roh

\section{kelelungan bangsawan)}

Kelelungan adalah roh akal budi yang berasal dari pemikiran manusia. Kelelungan yang disambut dalam prosesi pesalukng kelelungan merupakan Nayuq Timakng, yaitu para kelelungan bangsawan yang sudah berada di Telengkaq Langit Walo Lempir atau langit lapis ke delapan. Mereka merupakan roh yang jernih dan suci. Para bangsawan tidak akan sembarangan turun ke bumi apabila tidak dipanggil terlebih dahulu. Masyarakat Tonyooi
Benuaq tidak menyembah roh bangsawan, namun mereka menganggap rohyang suci dapat menjadi perantara yang baik antara mereka dengan Tuhan. Melalui perantaraan roh para bangsawan, Tuhan akan membimbing dan menuntun masyarakat Tonyooi Benuaq, serta melindungi mereka dari mara bahaya dan segala yang jahat.

Pesalukng liau (Menyambut kedatangan roh liau bangsawan)

Pesalukng liau berarti pengewara bersama anggota keluarga menyambut roh liau yang datang. Roh liau yang dijemput merupakan para bangsawan yang memiliki kuasa dan usianya sangat tua. Liau bangsawan sangat senang apabila mereka disambut dengan meriah. Itulah sebabnya dalam acara pesalukng liau banyak sekali permainan yang dibuat, seperti sabung ayam, naik pohon liau dan acara menari.

Sabung ayam atau saukng piak liau dijadikan alasan untuk dilegalkannya perjudian saat acara ini. Padahal filosofi dari sabung piak liau adalah ayam roh harus kalah, sehingga kesialan dan hal buruk dibawa para roh ke alam mereka. Tidak ada maksud untuk mencari keuntungan materi dalam kegiatan ini.

Tengua lou ja (Menunjukkan rumah para roh)

Ketika tengua lou ja, pengewara memberitahukan tempat kediaman para 
roh, yaitu surga mereka masing-masing. Harapannya agar liau melihat dan memeriksa tempat itu. Pengewara sebagai perwakilan dari roh-roh itu harus pergi ke kuburan, karena kuburan adalah tempat tinggal para roh yang dapat dilihat dengan mata manusia.

\section{Ukai Solai (Upacara Puncak)}

Pada upacara puncak dikorbankan hewan yang paling mahal, bisa berupa kerbau atau sapi. Kandang kerbau dibongkar kemudian kerbau dituntun untuk mengitari patung belontakng sebanyak tiga kali. Penombakan dilakukan oleh pihak keluarga hingga kerbau mati. Alasan kerbau harus ditombak karena memang itu yang dikehendaki para leluhur. Setelah kerbau mati, para pengewara bersama pihak keluarga menarik selampit yang mengikat kerbau sebanyak tujuh kali, tanda mereka bersuka ria karena hewan telah diterima oleh roh leluhur.

Pada hari puncak ini juga dilakukan tahapan terakhir tumakng wara. Masingmasing calon pengewara secara bergantian duduk di atas kerbau yang sudah mati. Kerbau yang mereka duduki merupakan tanda mereka telah membayar upah kepada para roh agar diluluskan menjadi pengewara. Setelah prosesi ini berakhir maka dua orang calon tersebut telah resmi menjadi pengewara. Malam harinya diadakan acara makan bersama yang melibarkan seluruh masyarakat sekitar.

\section{Mengantar roh kelelungan}

Pada malam harinya, pengewara mengantar roh kelelungan pulang ke surga mereka. Rangkaian acara ini diiringi dengan musik dan nyanyian. Sebelum pergi, kelelungan yang diwakili oleh pemimpin pengewara menyampaikan pesan-pesan kepada keluarga. Roh kelelungan pulang melalui jalan mereka datang, yaitu kain merah. Seluruh petugas kuangkai memegang kain merah bersama-sama. Terlihat raut kesedihan di wajah mereka karena ini adalah saat terakhir mereka dapat bersama-sama dengan roh kelelungan anggota keluarga mereka. Setelah kain merah digunting, tandanya roh-roh tersebut telah pulang ke surga mereka yang berada di atas langit.

\section{Mengantar roh liau}

Setelah roh kelelungan selesai diantar, sekarang saatnya pihak keluarga mengantar roh liau ke surga mereka. Upacara mengantar roh liau memakan waktu yang lebih lama bila dibandingkan dengan mengantar roh kelelungan. Ini karena surga roh liau terletak di dunia, namun di dimensi yang berbeda, yaitu di Gunung Lumut Kalimantan Tengah.

c. Segmen 3 (Penutup) Mengunjungi kuburan terakhir kali 
Pagi harinya perwakilan anggota keluarga mengantarkan peti-peti jenazah ke kuburan masing-masing. Tidak ada ritual lagi, karena malam tadi semua roh telah sampai pada tempat peristirahatan mereka. Lokasi kuburan yang berbeda- beda dan jarak yang jauh tidak memungkinkan untuk diikuti, karena pada saat yang bersamaan ada kegiatan di rumah acara.

\section{Pembagian upah}

Pada hari terakhir kuangkai ini ada acara pembagian lalus, yakni upah yang diberikan kepada roh pendamping pengewara. Upah tersebut bentuknya beraneka ragam, yaitu berupa separuh dari hasil kurban hewan-hewan yang disembelih dalam acara ini, uang, dan benda-benda lainnya. Pihak yang berhak menerima lalus adalah para pengewara karena mereka merupakan perwakilan dari roh-roh tersebut.

\section{Pembersihan keluarga}

Keluarga besar dimandikan oleh pemeliatn agar terhindar dari pengaruh buruk yang tersisa dari kuangkai. Biarlah segala hal negatif dibawa roh liau kelelungan bersama dengan kepulangan mereka ke alam baka. Terlihat ekspresi kebahagian dari seluruh keluarga karena mereka berhasil melaksanakan ritual ini dengan lancar dan tepat waktu.

\section{Kesimpulan}

Catatan etnografi merupakan suatu tulisan deskripsi kebudayaan yang keabsahannya didukung oleh hal-hal yang menggambarkan suasana budaya tersebut. Dokumenter etnografi merupakan sebuah karya film hasil refleksi dari sudut pandang masyarakat aslinya. Perbedaan antara catatan etnografi dengan dokumenter etnografi terdapat pada bentuk akhirnya. Catatan etnografi dalam bentuk data, sedangkan dokumenter etnografi dalam bentuk audiovisual.

Cara menyutradarai dokumenter etnografi yang baik adalah dengan terlebih dahulu mengenal secara mendalam obyek dan subyek dari dokumenter. Sutradara harus memiliki kedekatan yang intim dengan obyek dan subyek tersebut. Hal ini sangat mempermudah proses produksi karena saat proses pengambilan gambar, subyek menjadi mudah untuk diarahkan.

Kuangkai adalah sebuah prosesi panjang yang sebenarnya tidak wajib untuk dilaksanakan, akan tetapi pada akhirnya menjadi tanggung jawab moral bagi keluarga yang bersangkutan. Rasa terima kasih yang tidak sempat diungkapkan selama orang tersebut masih hidup dapat tersampaikan melalui kuangkai. Kuangkai merupakan adat istiadat masyarakat Tonyooi Benuaq yang terus dipegang teguh hingga saat ini. 


\section{Daftar Pustaka}

\section{Daftar Sumber Buku}

Ayawaila, Gerzon R. 2008. Dokumenter: Dari Ide Sampai Produksi. Jakarta: FFTV-IKJ Press.

Dyson, Laurentius \& Emanuel. 2013. Kebijakan Tentang Budaya Lokal. Surabaya: Fakultas Bahasa dan Seni bekerjasama dengan Dinas Kebudayaan, Pariwisata, Pemuda dan Olahraga Kutai Barat.

Koentjaraningrat. 2000. Pengantar Ilmu Antropologi. Jakarta: PT Rineka Cipta. 2010 Manusia dan Kebudayaan Indonesia. Jakarta: Djambatan.

Malinowski, Bronislaw. 1992. Argonauts of the Western Pacific. London: G. Routledge \& Sons.

Naratama. 2013. Menjadi Sutradara Televisi: dengan Single dan Multicamera.

Jakarta: Grasindo.

Pratista, Himawan. 2017. Memahami Film: Edisi 2. Yogyakarta: Montase Press.

Spradley, James P. 1997. Metode Etnografi. Yogyakarta: Tiara Wacana Yogya.

Widjono, Roedy Haryo. 2006. Dilema Transformasi Budaya Dayak. Samarinda: Nomaden Institute Cross Culture Studies.

\section{Daftar Sumber Online}

Durington, Matthew. 2013. “Etnographic Film". http://www.oxfordbibliographies.com/view/document/obo9780199766567/obo-97801997665670110. xml\#firstMatch. Diakses 14 Januari 2018.

Ruby, Jay. 1996. “Visual anthropology. In Encyclopedia of Cultural Anthropology.
Vol. 4". Disunting oleh David Levinson dan Melvin Ember, 1345-1351. New York: Henry Holt. 